\title{
PHYSICAL ACTIVITY, NUTRITION, AND BONE HEALTH
}

review paper

( ) University School of Physical Education in Wroclaw

DOI: https://doi.org/10.5114/hm.2018.77318

\section{ALESSANDRA AMATO $^{1}$, SARA BALDASSANO ${ }^{1}$, CRISTINA CORTIS $^{2}$, JILL COOPER ${ }^{1}$, PATRIZIA PROIA ${ }^{1}$}

${ }^{1}$ University of Palermo, Palermo, Italy

${ }^{2}$ University of Cassino and Southern Lazio, Cassino, Italy

\section{ABSTRACT}

This review aims to describe the roles that physical activity and nutrition have in bone metabolism and to examine their effects on bone in a situation of altered metabolism as a consequence of inadequate nutrition and/or excessive physical activity. Referring to the recent studies and the main guidelines in the literature on athlete nutrition, the paper also focuses on essential nutrients for bone health during performance. Finally, it discusses the negative effect of some nutrients on bone mineral density. Key words: osteoporosis, nutrition, bone metabolism, physical activity

\section{Introduction}

Bone tissue consists of specialized cells located in a mineralized matrix containing collagen fibres. The specific architecture and composition provides bone with exceptional solidity and resistance to pressure and traction. In spite of these characteristics and structural functions, bone is a living tissue, continuously changing during the phases of life. Bone remodelling takes place thanks to the balance between the demolition of the tissue by osteoclasts and its reconstruction by osteoblasts [1]. This process varies with age: during preadolescence, more than $50 \%$ of adult total bone mineral content (BMC) is obtained [2]; with aging, the activity of osteoblasts, producing new bone, can no longer completely replace bone tissue destroyed by osteoclasts, which leads to a loss of bone mass (i.e. osteopenia). When this loss is accentuated, the normal skeletal function becomes compromised, thus establishing a pathological condition known as osteoporosis. Osteoporosis is characterized by a decrease in the protein and mineral component of bone, with consequent skeletal microstructure alteration and fragility of bone, highly pre- disposed to fractures [3]. In particular, bone not only has the function of supporting and protecting the body, but it also intervenes in the balance of minerals, in the production of blood cells, and in numerous metabolic processes [4]. Furthermore, owing to its ability to produce osteocalcin, it can be defined as a true endocrine organ [5-7]. Being considered a metabolically active tissue, bone is in turn influenced by several factors such as sex hormones, growth hormone, insulin, diet (calcium, phosphate, vitamin D and A [8, 9]), and physical activity [10-12].

This review outlines the involvement of physical activity and nutrition in bone homeostasis.

\section{Physical activity and bone}

It is well established that many diseases can be prevented through physical activity [13]. Physical activity has a protective role against metabolic diseases, such as diabetes; furthermore, it helps prevent cardiovascular diseases (CVD) or manage hypertension [13]. Most studies have verified the influence of exercise on CVD mortality. Regarding bone metabolism, physical activity

Correspondence address: Patrizia Proia, Department of Psychological, Pedagogical and Educational Sciences, Sport and Exercise Sciences Research Unit, University of Palermo, Viale delle Scienze, Ed. 15 90128 Palermo, Italy, e-mail: patrizia.proia@unipa.it

Received: July 14, 2018

Accepted for publication: July 17, 2018

Citation: Amato A, Baldassano S, Cortis C, Cooper J, Proia P. Physical activity, nutrition, and bone health. Hum Mov. 2018; 19(4):1-10; doi: https://doi.org/10.5114/hm.2018.77318. 
A. Amato, S. Baldassano, C. Cortis, J. Cooper, P. Proia, Physical activity, nutrition, and bone health

is also important to stimulate bone growth and help maintain and restore adequate bone mineral density (BMD), both in pathological and non-pathological conditions, supporting the regeneration of bone tissue. Exercise stimulates the production of electric fields in the bone that activate osteoblasts, causing new bone matrix synthetization [14]. Therefore, as it has been demonstrated, moderate physical activity increases bone mass [15] and can provide an important contribution in cases of low BMD [16]. In turn, bone loss results from the removal of mechanical loading [17], caused by sedentary life [18], bed rest, low body weight [17], or significant weight loss due to excessive physical exercise without adequate nutrition. Therefore, mechanical signals generated by exercise can prevent a reduction in the musculoskeletal system, and exercise-related improvement in cortical thickness can be effective in increasing the bone mass of bone structure sites, especially the trabecular and cortical sites [15]. Physical activity influences bone metabolism also through hormone secretion and local factors [15]. Besides, intestinal $\mathrm{Ca}^{++}$absorption, energy metabolism, and the volume of skeletal muscles improved as a result of moderate exercise [19]. Therefore, the right amount and intensity of exercise combined with proper nutrition can be considered key factors to maintain adequate BMD. Although physical activity produces both mechanical and hormonal stimuli, the exact mechanisms underlying the exercise-related effect on bone metabolism are not clear.

\section{How mechanical stress regulates bone metabolism: a possible explanation}

Regarding mechanical stimulation, recent studies have shown that mechanical stress stimulates proliferation and differentiation of osteoblasts (the key cells involved in bone regulation) and inhibits the proliferation and activity of osteoclasts (the cells that regulate bone resorption and are essential for the balance of bone metabolism), modulating the anabolic and anticatabolic gene expression in bones, thus improving bone metabolism [20-22]. The mechanical stimulus provided by physical exercise seems to directly influence microRNA (miRNA), an abundant class of short non-coding RNA, molecules composed of about $22 \mathrm{nu}-$ cleotides [23]. MiRNA and protein translation are involved in multiple biological processes including cell proliferation, differentiation, survival, transposing silencing [24], and self-renewal of stem cells [25]. MiRNA has been shown to play a regulatory role in bone metabolism [26, 27], in mesenchymal bone marrow stem cells (BMSC) and in osteoblasts [28], which suggests that miRNAs could be one of the main mechanisms by which exercise or mechanical load regulate bone metabolism and promote bone formation. MiRNAs regulate the proliferation and differentiation of osteoblasts and osteoclasts and, subsequently, bone metabolism [29]. However, the numerous miRNAs can play different and opposite roles: while some promote osteoblast proliferation and differentiation, others have been shown to inhibit osteoblast proliferation and differentiation [30]. Lack of mechanical stimuli, as experienced by patients bedridden or under microgravity conditions, results in osteoporosis [17, 31, 32], although miRNAs are not the only mechanism by which mechanical stress regulates bone metabolism. However, it is shown that they are influenced by mechanical loading effects on bone formation by modulating the expression of osteogenic factors or bone resorption factors. The response of bone cells to a mechanical stress stimulus is negatively affected when critical miRNAs are lacking.

\section{Adequate physical activity and bone metabolism}

Although numerous studies report that trained subjects have a greater BMD (osteogenic effect) compared with untrained ones [33, 34], it is crucial to identify the volume, intensity, and frequency of training suitable for stimulating osteogenic activity. Below, some of the different types of training responsible for the osteogenic effect are described.

\section{Resistance training vs. aerobic activities}

Recent studies show that resistance training helps maintain homeostasis and has numerous metabolic effects [35].

Bone deformation during resistance training is associated with higher improvement in BMD as compared with exercise performed at a lower intensity, e.g. running results in more mechanical stress than aerobic activity [36-39]. As the magnitude of the stimulus proved to be more important than its frequency [37-40], a relationship between BMD and the level of muscular strength could be hypothesized [39, 41, 42], although the type of muscular contraction also plays a key role. In particular, an eccentric contraction stimulates the bone more than a concentric contraction [43, 44], and it is therefore more effective in BMD increasing [45]. For example, comparing concentric and eccentric contractions trainings for the knee extensors and flexors, 
Hawkins et al. [45] showed that only subjects who administered eccentric training had a increase of 3.9\% in the femoral BMD. These results were confirmed in a recent study [46] in which cyclic mechanical stretch was shown to up-regulate the protein expression of Runx2 and promote osteoblast proliferation, which explains the biomolecular mechanisms in the bone during the eccentric and elongation phase.

\section{Osteoporosis prevention with physical activity}

As strength training is an important form of exercise for bone growth, there are other activities recommended for the prevention of osteoporosis by health organizations [47, 48]. Weight-bearing exercises, high impact exercises such as jumping, plyometric training (jumping/hopping), and weight lifting [49] have positive effects on bone, regardless of age [50]. The subject's age is another important factor of physical exercise effect on bone metabolism because the bone response to mechanical stress changes during lifetime. In adolescence, resistive exercise can increase bone strength [51], whereas during middle age and after puberty it can help to reduce loss of bone mass and density [50]. The combination of high impact or weight-bearing and aerobic training can prevent age-related bone loss [52] but aerobic activities, such as cycling, walking, yoga, and swimming, are not osteogenic [52]. Therefore, to provide the magnitude of load necessary to maintain bone mass and density, it is crucial to combine low-load activities, such as aerobics, with resistance exercises.

Possible negative effects of excessive physical activity on bone

Physical activity inadequate in volume and intensity could have negative effects on bone metabolism, leading to a loss of BMD up to osteoporosis when very intense physical exercise is associated with inadequate caloric intake (in particular, that of specific nutrients) [53] and low starting BMD. Bone stress as a consequence of high-intensity physical activity can be more easily manifested in women. As female sex hormones (oestrogens) play a key role in bone metabolism and their concentration can be influenced by physical exercise [54], high intensity of endurance training might lead to an early bone loss due to an excessive decrease in body fat. Therefore, low level of oestrogen synthesis substrate and the effects of the female sexual hormones on the bone homeostasis are altered [54]. Although there is a bone strengthening effect of physical activities with overload, intense training may cause low hor- monal production, with a negative effect on the axial bone health, mainly in women. However, the bone loss in this case occurs because of a caloric deficit, and an appropriate nutritional diet could help avoid these hormonal disturbances in female athletes [55-57].

\section{Nutrition effects on physical activity and bone. General considerations for athletes' nutrition}

To guarantee the necessary energy for intense physical activity and to help avoid the aforementioned problems, adequate diet must include the right contribution of all the main nutrients, as enumerated below.

\section{Fat}

Lipids (or fats) are organic compounds widely diffused in nature, representing one of the four main classes of organic compounds of biological interest, together with carbohydrates, proteins, and nucleic acids. They constitute an important energy reserve, especially during long-term exercise, being the main sources of skeletal muscle adenosine triphosphate (ATP) production [58]. Chronic exercise training results in favourable mitochondrial adaptations in adults, which enhance lipid metabolism as well [59], although gender differences in relative fat and carbohydrate oxidation during exercise exist [60]. Dietary lipids are essential for the absorption of vitamins and for sex hormones homeostasis [61]. In terms of caloric requirements, most sources recommend that lipid intake should be limited to $25-30 \%$ of the total caloric intake. Nonetheless, caloric demands are increased in athletes [62], and lipids are important to produce hormones involved in healthy growth, maturation, and bone metabolism [63]. Ingested lipids differ in the composition of the hydrocarbon chain and this can affect the metabolism [64, 65]. In particular, monounsaturated fatty acids can potentially have a favourable effect on body composition [66]; fish oil and conjugated linoleic acid could exert ergogenic and anabolic effects on exercise, being also related to increased testosterone synthesis.

\section{Protein}

Proteins are biological macromolecules made up of chains of amino acids linked to one another by a peptide bond. Their functions are mainly structural and synthesis-related, but they also play a role in energetic processes, although in a lower percentage compared with carbohydrates and fats, with a greater thermic 
A. Amato, S. Baldassano, C. Cortis, J. Cooper, P. Proia, Physical activity, nutrition, and bone health

effect [67]. Consequently, they are fundamental to guarantee a good physical performance. The adequate protein intake indicated by the American College of Sports Medicine (ACSM) is $1.2-1.8 \mathrm{~g} / \mathrm{kg}$ of body mass for active adults $[68,69]$, with athletes requiring higher protein intake to maintain protein synthesis [70]. In particular, a recent study has shown that the ingestion of $20 \mathrm{~g}$ of protein post-exercise helps maintain positive protein balance following exercise [71].

\section{Carbohydrate}

Glucides or glycides are organic chemical compounds formed of carbon, hydrogen, and oxygen atoms, constituting the carbohydrate biomolecule class. On the basis of their chemical structure, carbohydrates are classified into simple and complex and some confusion exists in athletes' understanding of specific carbohydrate needs. General carbohydrate intake recommendations suggest adult athletes to consume 5-12 g of carbohydrate per kilogram per day but this dependent on different exercise/activity, its intensity, duration, and volume, as well as the environmental conditions in which physical activity takes place. Moreover, as men and women are biologically different, they react differently to physical exercise and consequently the caloric intake, especially from carbohydrates, should be adapted to their needs [72]. It is therefore difficult to suggest the exact carbohydrate intake necessary for an athlete during particular activities. However, Burke et al. [72] suggested that carbohydrate ingestion during activities lasting 45 minutes or longer provides an ergogenic effect with doses varying from small ones up to $90 \mathrm{~g} /$ hour, whereas ACSM recommends that athletes should ingest simple sugars at the rate of 30-60 g/hour for exercise lasting longer than 60 minutes. Additionally, Amato et al. [69] showed that gymnastics performance improved after eating a carbohydrate snack compared with a different pre-exercise meal.

\section{Micronutrients}

Micronutrients, subdivided into vitamins and minerals, are ingested substances whose main function is not directly related to energy production and growth. Among vitamins most important for homeostasis, vitamin A is involved in immune function, vision, reproduction, and cellular communication [73-75], also supporting cell growth and differentiation [76], whereas vitamin $B_{12}$ helps keep the nerve and blood cells healthy and supports DNA synthesis, also preventing megaloblastic anaemia, which makes people tired and weak
[77]. Furthermore, being important in the cross-linking of collagen fibres in bone [77], vitamin C (ascorbic acid) is a cofactor in the hydroxylation of lysine and proline, whereas vitamin $\mathrm{K}$ is a cofactor in the gammacarboxylation of glutamic acid, important in the production of osteocalcin [78, 79].

One of the most important minerals for homeostasis is magnesium, involved in bone and mineral homeostasis, crucial for bone crystal growth and stabilization. Magnesium, along with other nutrients found in fruit and vegetables, contributes to an alkaline environment and may promote bone health through a variety of mechanisms, therefore it is difficult to examine the effects of magnesium alone. The recommended dietary allowances (RDAs) for magnesium are 400$420 \mathrm{mg}$ daily for males and 300-320 mg daily for females [80].

Phosphorus is an essential bone-forming element and, as in the case of calcium, an adequate supply of phosphorus to bone is necessary throughout life. Both calcium and phosphorus are required for an appropriate mineralization of the skeleton, and a depletion of serum phosphate leads to impaired bone mineralization, compromising osteoblast function [81]. Furthermore, a combined supplement of calcium, zinc, manganese, and copper produced increases in BMD [82]. Finally, boron has effects on urinary calcium excretion and associations with BMD have been reported [83].

As higher BMD has been associated with a higher dietary potassium intake [80], the electrolytes of sodium and potassium play an important role in the development and prevention of osteoporosis. The adequate intake for potassium is $4700 \mathrm{mg}$ daily for males and females [80].

Another essential component is iron, involved in erythrocyte protein, haemoglobin, which transfers oxygen from the lungs to the tissues [84]. It is also necessary for growth, development, normal cellular functioning, and synthesis of some hormones and connective tissue [75, 85]. The RDAs for iron are 8-11 mg daily for males and 8-15 mg daily for females [75]. Athletes will likely find additional benefit from including other iron-rich foods, such as peanuts, dried fruit, and ironfortified cereals as regular snacks. Furthermore, the inclusion of foods higher in ascorbic acid with these nonheme iron sources will improve iron absorption from these snacks [85].

\section{Athletes' nutrition for bone health}

Low energy availability due to exhausting physical exercise linked with failure of diet intake of the above- 
mentioned nutrients can impair bone health. In particular, values below the minimum energy threshold $\left(30 \mathrm{kcal} \cdot \mathrm{kg}\right.$ lean body mass $\left.[\mathrm{LBM}]^{-1} \cdot \mathrm{d}^{-1}\right)[86]$ can alter physiological mechanisms such as cell repair, thermoregulation, immunity, growth, and bone turnover through the distorted levels of metabolic hormones and substrates, such as growth hormone, cortisol, fatty acids, and glucose among the most important ones [87]. Under this threshold, the levels of carboxyterminal propeptide of type 1 procollagen (P1CP) and osteocalcin, the matrix mineralization measure, were significantly reduced [88]. The minimum energy threshold for athletes' population has been identified as $45 \mathrm{kcal} \cdot \mathrm{kg} \mathrm{LBM}^{-1} \cdot \mathrm{d}^{-1}$ [86], depending on many factors, such as the different types of physical activities, environmental conditions, and physical characteristics of each athlete. As an example, elite runners need $6 \mathrm{kcal} \cdot \mathrm{kg} \mathrm{LBM}^{-1} \cdot \mathrm{d}^{-1}$ [88], while triathletes require $24-33 \mathrm{kcal} \cdot \mathrm{kg} \mathrm{LBM}^{-1} \cdot \mathrm{d}^{-1}$ [89].

\section{Carbohydrate and protein intake}

With a mixed meal, calcium, glucose, protein can supresses bone resorption at rest [90]. Gastric inhibitory polypeptide (GIP) and glucagon-like peptide-2 (GLP-2) are potential mediators of the post-prandial regulation of bone turnover [91]. Henriksen et al. [90] showed that only GLP-2 was secreted with glucose and protein ingestion and was in parallel with the suppression of beta C-terminal telopeptide ( $\beta$-CTX). The effects of carbohydrate supplementation during intermittent running is bound with bone turnover markers (a carbohydrate beverage including $1 \mathrm{~g} \cdot \mathrm{kg}$ body mass $[\mathrm{BM}]^{-1}$ of maltodextrin reduced $\beta$-CTX, increased bone formation, and decreased resorption) [92]. Another study demonstrated that a carbohydrate drink (glucose) before, during, and after running exercise at $70 \% \mathrm{VO}_{2 \max }$ attenuated procollagen type $1 \mathrm{ami}$ no-terminal propeptide (P1NP) responses [93]. The same author showed that a carbohydrate drink attenuated the rise in the circulating interleukin 6 (IL-6), an osteoclastogenesis activator associated with exercise. Moreover, eating in close proximity to exercise also suppresses bone resorption at rest but can cause gastrointestinal discomfort, impairing performance [94]. Simple carbohydrates and proteins are not likely to cause gastrointestinal complaints as they contain little fibre or fat, which means that digestion is quick [95]. A carbohydrate + protein recovery drink consumed immediately post-exercise is beneficial for endurance athletes [96], in whom the ingestion of a carbohydrate + protein solution (containing $1.5 \mathrm{~g} \cdot \mathrm{kg} \mathrm{BM}^{-1}$ of carbohydrate and $0.5 \mathrm{~g} \cdot \mathrm{kg} \mathrm{BM}^{-1}$ of protein) immediately after an exhaustive run suppressed $\beta$-CTX concentrations, although a delayed ingestion of the carbohydrate + protein solution ( 2 hours post-exercise) also resulted in a large suppression of $\beta$-CTX concentrations.

\section{$\mathrm{Ca}^{++}$and vitamin D intake}

Calcium is a key factor to keep human body homeostasis. It is involved in many vital functions, such as cellular processes including exocytosis, neurotransmitter release, muscle contraction, and the proliferation of action potentials through the cardiac muscle. Bone is the largest reservoir of calcium in the body and reductions in serum ionized calcium are therefore mitigated by demineralization of bone, a process stimulated by increases in the parathyroid hormone (PTH). The cross-linked C-telopeptide of type I collagen (CTX-I) and, more recently, cross-linked C-telopeptide of type II collagen (CTX-II) have been indicated as sensitive markers of osteoclastic bone resorption, while the procollagen I N-terminal propeptide (PINP) is determined as a marker of osteoblastic bone formation [97]. Furthermore, calcium absorption is dependent on adequate levels of vitamin D [98]. Vitamin D is obtained either from the diet or by synthesis in the skin under the action of sunlight. The report on dietary reference intakes for calcium and vitamin D by Ross et al. [98] shows that all individuals meet their needs at RDAs for vitamin D, at 25-hydroxyvitamin D (25(OH)D) levels of at least $20 \mathrm{ng} / \mathrm{ml}$ (50 nmol/l) even under conditions of minimal sun exposure [98]. Associations have been reported between plasma 25(OH)D and BMD in middle-aged and older women [99, 100]. Supplementation with calcium and vitamin $\mathrm{D}$ together resulted in sizeable reductions BMD loss; bone loss was limited to subjects with a daily calcium intake below $400 \mathrm{mg}$ $[77,101]$. However, it is not clear what the pre-exercise meal able to guarantee the right amount of calcium to an athlete is, especially during long-lasting and high-intensity sports, when there is a great sweat calcium loss. For example, it has been observed that $\sim 1000 \mathrm{mg}$ calcium supplement pre- or post-exercise reduces bone resorption markers levels [94, 102]. A recent study by Haakonssen et al. [94] shows that a calciumrich pre-exercise meal can maintain serum ionised calcium and reduce post-exercise increase of PTH and CTX-I, especially among endurance athletes.

\section{Good foods and bad foods for bone health}

The interaction between food supplementation, sport, and bone health is complex. Recent studies show that 
A. Amato, S. Baldassano, C. Cortis, J. Cooper, P. Proia, Physical activity, nutrition, and bone health

in addition to the integration of 'positive' nutrients for bone homeostasis, there are some foods that, on the contrary, can be negatively related to BMD if taken in excess. For athletes with chronic energy deficiency, an excess of fibre, phytic and oxalic acids, isoflavones, and vegetable proteins with an imbalance of other essential macro- and micronutrients can be detrimental to bone health [67]. Dietary fibre can influence the energy availability and digestibility of complex foods. It can interact with proteins and fats and decrease the metabolizable energy of a diet, influencing the digestibility of these components [103]. Because dietary fibre increases most intestinal contents and accelerates calcium and other minerals transit time in the intestine, it causes loss of time to absorb these nutrients. Foods rich in phytic acid, such as wheat bran, legumes, seeds, nuts, and soy isolates, can reduce bioavailability and thus prevent the beneficial effects of nutrients such as calcium, magnesium, and protein on the bones [67]. Dietary fibre is inversely associated with the levels of the luteinizing hormone, follicle-stimulating hormone, oestradiol, and progesterone [104], and oestrogen plays a significant defensive role in oxidative stress [105] and attenuates bone endocortical reabsorption [106]. Moreover, it is already clear that reactive oxygen species (ROS) induce the apoptosis of osteoblasts and osteocytes; this inhibits osteogenesis, favouring osteoclastogenesis. Antioxidants like polyphenols and anthocyanins, the most abundant antioxidants in the diet, counteract the action of oxidants, contributing to the prevention of bone loss [107]. Specific nutritional approaches suggest the antioxidant use to counteract the resorption. Excess consumption of such foods is predominant in sports in which aesthetics and the maintenance of adequate weight are essential. However, further studies are needed to provide understanding of the recommended quantity of this type of food and the athlete's starting condition that can cause osteopenia.

\section{Conclusion}

The objective of this review was to point out how nutrition and physical activity interact with each other and how they affect bone metabolism. This issue is important for the prevention of bone disease such as osteoporosis. Bone health constitutes a crucial aspect for an athlete. Bone metabolism is the basis of good musculoskeletal system function and thus favourable performance, which is in turn strongly related to the right energy derived from nutrients intake. Recent studies show how bone metabolism, diet, and training are interconnected and crucial for elite athletes. Although the purpose of this review was to clarify how these elements interact with each other, further studies are necessary to illustrate some other key elements, such as adequate bone markers to be used to monitor bone health, the exact quantity and quality of nutrients in the diet, and the correct volume, frequency, and intensity of training with the consideration of the biological characteristics of an athlete.

\section{Ethical approval}

The conducted research is not related to either human or animal use.

\section{Disclosure statement}

No author has any financial interest or received any financial benefit from this research.

\section{Conflict of interest}

The authors state no conflict of interest.

\section{References}

1. Frost HM. Dynamics of bone remodeling in bone biodynamics. Boston: Little and Brown; 1964.

2. Kambas A, Leontsini D, Avloniti A, Chatzinikolaou A, Stampoulis T, Makris K, et al. Physical activity may be a potent regulator of bone turnover biomarkers in healthy girls during preadolescence. J Bone Miner Metab. 2017;35(6):598-607; doi: 10.1007/s00774-016-0794-3.

3. Yuan Y, Zhang L, Tong X, Zhang M, Zhao Y, Guo J, et al. Mechanical stress regulates bone metabolism through microRNAs. J Cell Physiol. 2017;232(6):1239-1245; doi: 10.1002/jcp.25688.

4. Fernandes T, Gonçalves L, Brito J. Relationships between bone turnover and energy metabolism. J Diabetes Res. 2017;9021314; doi: 10.1155/2017/9021314.

5. Zoch ML, Clemens TL, Riddle RC. New insights into the biology of osteocalcin. Bone. 2016;82:42-49; doi: 10.1016/j.bone.2015.05.046.

6. Ferron M, Lacombe J. Regulation of energy metabolism by the skeleton: osteocalcin and beyond. Arch Biochem Biophys. 2014;561:137-146; doi: 10.1016/j.abb.2014. 05.022 .

7. Karsenty G, Oury F. Biology without walls: the novel endocrinology of bone. Annu Rev Physiol. 2012;74:87105; doi: 10.1146/annurev-physiol-020911-153233.

8. Otten JJ, Hellwig JP, Meyers LD (eds.). Dietary reference intakes: the essential guide to nutrient requirements. Washington: National Academies Press; 2006. Available from: http://nap.edu/openbook.php?record _id=11537.

9. Institute of Medicine. Dietary reference intakes for calcium and vitamin D. Washington: Institute of Medicine; 2010. Available from: http://www.nationalacademies. org/hmd/ /media/Files/Report\%20Files/2010/Die- 
tary-Reference-Intakes-for-Calcium-and-Vitamin-D/ Vitamin\%20D\%20and\%20Calcium\%202010\%20Report $\% 20$ Brief.pdf.

10. Hinton PS, Nigh P, Thyfault J. Effectiveness of resistance training or jumping-exercise to increase bone mineral density in men with low bone mass: a 12-month randomized, clinical trial. Bone. 2015;79:203-212; doi: 10.1016/j.bone.2015.06.008.

11. Kemmler W, Bebenek M, von Stengel S, Bauer J. Peakbone-mass development in young adults: effects of study program related levels of occupational and leisure time physical activity and exercise. Osteoporos Int. 2015; 26(2):653-662; doi: 10.1007/s00198-014-2918-8.

12. Kish K, Mezil Y, Ward WE, Klentrou P, Falk B. Effects of plyometric exercise session on markers of bone turnover in boys and young men. Eur J Appl Physiol. 2015; 115(10):2115-2124; doi: 10.1007/s00421-015-3191-z.

13. Paoli A, Bianco A. What is fitness training? Definitions and implications: a systematic review article. Iran J Public Health. 2015;44(5):602-614.

14. Wang QS, Zhang XC, Li RX, Sun JG, Su WH, Guo Y, et al. A comparative study of mechanical strain, icariin and combination stimulations on improving osteoinductive potential via NF-kappaB activation in osteoblast-like cells. Biomed Eng Online. 2015;14:46; doi: 10.1186 /s12938-015-0039-z.

15. Omi N. Influence of exercise and sports on bone. J Phys Fitness Sports Med. 2014;3(2):241-248; doi: 10.7600/ jpfsm.3.241.

16. Ooi FK, Sahrir NA. Physical activity, bone remodelling and bone metabolism markers. J Exerc Sports Orthop. 2018;5(2):1-4; doi: 10.15226/2374-6904/5/2/00171.

17. Ohshima H, Matsumoto T. Space flight/bedrest immobilization and bone. Bone metabolism in space flight and long-duration bed rest [in Japanese]. Clin Calcium. 2012;22(12):1803-1812; doi: CliCa121218031812.

18. Rahim M, Ooi FK, Hamid WZWA. Changes of bone metabolism markers and muscular performance with combined aerobic dance exercise and honey supplementation in adult women. Sports Exerc Med Open J. 2016;1(6):186-197; doi: 10.17140/ SEMOJ-1-129.

19. Ooi FK, Aziz A. Bone metabolism markers in response to circuit training and honey supplementation in young males. Malays J Med Res. 2017;1(4):28-34.

20. Thompson WR, Rubin CT, Rubin J. Mechanical regulation of signaling pathways in bone. Gene. 2012;503(2): 179-193; doi: 10.1016/j.gene.2012.04.076.

21. Rochefort GY, Benhamou CL. Osteocytes are not only mechanoreceptive cells. Int J Numer Method Biomed Eng. 2013;29(10):1082-1088; doi: 10.1002/cnm.2561.

22. Zhao L, Shim JW, Dodge TR, Robling AG, Yokota H. Inactivation of Lrp5 in osteocytes reduces young's modulus and responsiveness to the mechanical loading. Bone. 2013;54(1):35-43; doi: 10.1016/j.bone.2013.01.033.

23. Luna C, Li G, Qiu J, Epstein DL, Gonzalez P. MicroRNA-24 regulates the processing of latent TGF $\beta 1$ during cyclic mechanical stress in human trabecular mesh- work cells through direct targeting of FURIN. J Cell Physiol. 2011;226(5):1407-1414; doi: 10.1002/jcp.22476.

24. Schiera G, Contrò V, Sacco A, Macchiarella A, Cieszczyk P, Proia P. From epigenetics to anti-doping application: a new tool of detection. Hum Mov. 2017;18(1):3-10; doi: 10.1515/humo-2017-0005.

25. Goff LA, Boucher S, Ricupero CL, Fenstermacher S, Swerdel M, Chase LG, et al. Differentiating human multipotent mesenchymal stromal cells regulate microRNAs: prediction of microRNA regulation by PDGF during osteogenesis. Exp Hematol. 2008;36(10):13541369; doi: 10.1016/j.exphem.2008.05.004.

26. Inose H, Ochi H, Kimura A, Fujita K, Xu R, Sato S, et al. A microRNA regulatory mechanism of osteoblast differentiation.ProcNatlAcadSciUSA.2009;106(49):2079420799; doi: 10.1073/pnas.0909311106.

27. Kook SH, Son YO, Hwang JM, Kim EM, Lee CB, Jeon $\mathrm{YM}$, et al. Mechanical force inhibits osteoclastogenic potential of human periodontal ligament fibroblasts through OPG production and ERK-mediated signaling. J Cell Biochem. 2009;106(6):1010-1019; doi: 10.1002/ jcb. 22086.

28. Guo Y, Wang Y, Liu Y, Liu Y, Zeng Q, Zhao Y, et al. MicroRNA-218, microRNA-191*, microRNA-3070a and microRNA-33 are responsive to mechanical strain exerted on osteoblastic cells. Mol Med Rep. 2015;12(2): 3033-3038; doi: 10.3892/mmr.2015.3705.

29. Hassan MQ, Gordon JA, Beloti MM, Croce CM, van Wijnen AJ, Stein JL, et al. A network connecting Runx2, SATB2, and the miR-23a 27a 24-2 cluster regulates the osteoblast differentiation program. Proc Natl Acad Sci USA. 2010;107(46):19879-19884; doi: 10.1073/ pnas.1007698107.

30. Nakasa T, Shibuya H, Nagata Y, Niimoto T, Ochi M. The inhibitory effect of microRNA-146a expression on bone destruction in collagen-induced arthritis. Arthritis Rheum. 2011;63(6):1582-1590; doi: 10.1002/art.30321.

31. Blaber EA, Dvorochkin N, Torres ML, Yousuf R, Burns BP, Globus RK, et al. Mechanical unloading of bone in microgravity reduces mesenchymal and hematopoietic stem cell-mediated tissue regeneration. Stem Cell Res. 2014;13(2):181-201; doi: 10.1016/j.scr.2014.05.005.

32. Sambandam Y, Townsend MT, Pierce JJ, Lipman CM, Haque A, Bateman TA, et al. Microgravity control of autophagy modulates osteoclastogenesis. Bone. 2014; 61:125-131; doi: 10.1016/j.bone.2014.01.004.

33. Stone TM, Wingo JE, Young JC, Navalta JW. An evaluation of select physical activity exercise classes on bone metabolism. Int J Exerc Sci. 2018;11(2):452-461.

34. Pellikaan P, Giarmatzis G, Vander Sloten J, Verschueren S, Jonkers I. Ranking of osteogenic potential of physical exercises in postmenopausal women based on femoral neck strains. PLoS One. 2018;13(4):e0195463; doi: 10.1371/journal.pone.0195463.

35. Paoli A, Moro T, Bianco A. Lift weights to fight overweight. Clin Physiol Funct Imaging. 2015;35(1):1-6; doi: 10.1111/cpf.12136. 
A. Amato, S. Baldassano, C. Cortis, J. Cooper, P. Proia, Physical activity, nutrition, and bone health

36. Kerr D, Ackland T, Maslen B, Morton A, Prince R. Resistance training over 2 years increases bone mass in calcium-replete in postmenopausal women. J Bone Miner Res.2001;16(1):175-181;doi:10.1359/jbmr.2001.16.1.175.

37. Nichols DL, Sanborn CF, Essery EV. Bone density and young athletic women. Sports Med. 2007;37(11):10011014; doi: 10.2165/00007256-200737110-00006.

38. Tenforde AS, Fredericson M, Sayres LC, Cutti P, Sainani KL. Identifying sex-specific risk factors for low bone mineral density in adolescent runners. Am J Sports Med. 2015;43(6):1494-1504; doi: 10.1177/03635465 15572142 .

39. De Smet S, Michels N, Polfliet C, Sara D’Haese S, Roggen I, De Henauw $S$, et al. The influence of dairy consumption and physical activity on ultrasound bone measurements in Flemish children. J Bone Miner Metab. 2015;33(2): 192-200; doi: 10.1007/s00774-014-0577-7.

40. Burrows M, Nevill AM, Bird S, Simpson D. Physiological factors associated with low bone mineral density in female endurance runners. Br J Sports Med. 2003; 37(1):67-71.

41. Duplanty AA, Levitt DE, Hill DW, McFarlin BK, DiMarco NM, Vingren JL. Resistance training is associated with higher bone mineral density among young adult male distance runners independent of physiological factors. J Strength Cond Res. 2018;32(6):15941600; doi: 10.1519/JSC.0000000000002504.

42. Senderovich H, Kosmopoulos A. An insight into the effect of exercises on the prevention of osteoporosis and associated fractures in high-risk individuals. Rambam Maimonides Med J. 2018;9(1):e0005; doi: 10.5041/ RMMJ.10325.

43. Aagaard P, Simonsen EB, Andersen JL, Magnusson SP, Halkjaer-Kristensen J, Dyhre-Poulsen P. Neural inhibition during maximal eccentric and concentric quadriceps contraction: effects of resistance training. J Appl Physiol. 2000;89(6):2249-2257; doi: 10.1152/jappl. 2000.89.6.2249.

44. Hortobágyi T, Hill JP, Houmard JA, Fraser DD, Lambert NJ, Israel RG. Adaptive responses to muscle lengthening and shortening in humans. J Appl Physiol. 1996; 80(3):765-772; doi: 10.1152/jappl.1996.80.3.765.

45. Hawkins SA, Schroeder ET, Wiswell RA, Jaque SV, Marcell TJ, Costa K. Eccentric muscle action increases sitespecific osteogenic response. Med Sci Sports Exerc. 1999;31(9):1287-1292; doi: 10.1097/00005768-19990 9000-00009.

46. Zuo B, Zhu J, Li J, Wang C, Zhao X, Cai G, et al. MicroRNA-103a functions as a mechanosensitive microRNA to inhibit bone formation through targeting Runx2. J Bone Miner Res. 2015;30(2):330-345; doi: 10.1002/ jbmr.2352.

47. National Osteoporosis Foundation. Osteoporosis exercise for strong bones. Available from: https://www.nof. org/patients/fracturesfall-prevention/exercisesafemovement/osteoporosis-exercise-for-strong-bones.
48. National Institute of Arthritis and Musculoskeletal and Skin Diseases. Handout on health: osteoporosis. Available from: https://www.bones.nih.gov/health-info/bone/ osteoporosis/osteoporosis-hoh.

49. Fuchs RK, Bauer JJ, Snow CM. Jumping improves hip and lumbar spine bone mass in prepubescent children: a randomized controlled trial. J Bone Miner Res. 2001; 16(1):148-156; doi: 10.1359/jbmr.2001.16.1.148.

50. Harding AT, Beck BR. Exercise, osteoporosis, and bone geometry. Sports. 2017;5(2):29; doi: 10.3390/sports50 20029.

51. Tan VP, Macdonald HM, Kim S, Nettlefold L, Gabel L, Ashe MC, et al. Influence of physical activity on bone strength in children and adolescents: a systematic review and narrative synthesis. J Bone Miner Res. 2014; 29(10):2161-2181; doi: 10.1002/jbmr.2254.

52. Gómez-Cabello A, Ara I, González-Agüero A, Casajús JA, Vicente-Rodríguez G. Effects of training on bone mass in older adults: a systematic review. Sports Med. 2012; 42(4):301-325; doi: 10.2165/11597670-00000000000000.

53. Barron E, Cano Sokoloff N, Maffazioli G, Ackerman KE, Woolley R, Holmes TM, et al. Diets high in fiber and vegetable protein are associated with low lumbar bone mineral density in young athletes with oligoamenorrhea. J Acad Nutr Diet. 2016;116(3):481-489; doi: 10.1016/j. jand.2015.10.022.

54. Cano Sokoloff N, Eguiguren ML, Wargo K, Ackerman KE, Baskaran C, Singhal V, et al. Bone parameters in relation to attitudes and feelings associated with disordered eating in oligo-amenorrheic athletes, eumenorrheic athletes, and nonathletes. Int J Eat Disord. 2015; 48(5):522-526; doi: 10.1002/eat.22405.

55. Ganong WF. Medical Physiology [in Portuguese], $19^{\text {th }}$ ed. São Paulo: McGraw-Hill Companies; 1999.

56. Helge EW, Kanstrup IL. Bone density in female elite gymnasts: impact of muscle strength and sex hormones. Med Sci Sports Exerc. 2002;34(1):174-180; doi: 10.1097/ 00005768-200201000-00026.

57. Gremion G, Rizzoli R, Slosman D, Theintz G, Bonjour JP. Oligo-amenorrheic long-distance runners may lose more bone in spine than in femur. Med Sci Sports Exerc. 2001;33(1):15-21; doi: 10.1097/00005768-20010100000004.

58. Bjorntorp P. Importance of fat as a support nutrient for energy: metabolism of athletes. J Sports Sci. 1991;9: 71-76; doi: 10.1080/02640419108729867.

59. Tunstall RJ, Mehan KA, Wadley GD, Collier GR, Bonen A, Hargreaves M, et al. Exercise training increases lipid metabolism gene expression in human skeletal muscle. Am J Physiol Endocrinol Metab. 2002;283(1): E66-E72; doi: 10.1152/ajpendo.00475.2001.

60. Aucouturier J, Baker JS, Duché P. Fat and carbohydrate metabolism during submaximal exercise in children. Sports Med. 2008;38(3):213-238; doi: 10.2165/0000 7256-200838030-00003. 
61. Lichtenstein AH, Kennedy E, Barrier P, Danford D, Ernst ND, Grundy SM, et al. Dietary fat consumption and health. Nutr Rev. 1998;56(5 Pt 2):S3-S28; doi: 10.1111/j.1753-4887.1998.tb01728.x.

62. Smith JW, Jeukendrup A. Performance nutrition for young athletes. In: Bagchi D, Nair S, Sen C (eds.), Nutrition and enhanced sports performance: muscle building, endurance, and strength. London: Elsevier; 2013; 523-529.

63. Bushman BA. Calorie requirements for young competitive female athletes. ACSM Health Fitness J. 2012; 16(5):4-8; doi: 10.1249/FIT.0b013e318264c8b3.

64. Cooper JA, Watras AC, Shriver T, Adams AK, Schoeller DA. Influence of dietary fatty acid composition and exercise on changes in fat oxidation from a high-fat diet. J Appl Physiol. 2010;109(4):1011-1018; doi: 10.1152/ japplphysiol.01025.2009.

65. Smith JW, Holmes ME, McAllister MJ. Nutritional considerations for performance in young athletes. J Sports Med. 2015; 2015:734649; doi: 10.1155/2015/ 734649 .

66. Piers LS, Walker KZ, Stoney RM, Soares MJ, O’Dea K. Substitution of saturated with monounsaturated fat in a 4-week diet affects body weight and composition of overweight and obese men. Br J Nutr. 2003;90(3):717727; doi: 10.1079/BJN2003948.

67. Halton TL, Hu FB. The effects of high protein diets on thermogenesis, satiety and weight loss: a critical review. J Am Coll Nutr. 2004;23(5):373-385; doi: 10.1080/ 07315724.2004 .10719381$.

68. Phillips SM, Van Loon LJ. Dietary protein for athletes: from requirements to optimum adaptation. J Sports Sci. 2011;29(Suppl. 1):S29-S38; doi: 10.1080/02640414. 2011.619204.

69. Amato A, Sacco A, Macchiarella A, Contrò V, Sabatino E, Galassi C, et al. Influence of nutrition and genetics on performance: a pilot study in a group of gymnasts. Hum Mov. 2017;18(3):12-16; doi: 10.1515/humo2017-0029.

70. Duellman MC, Lukaszuk JM, Prawitz AD, Brandenburg JP. Protein supplement users among high school athletes have misconceptions about effectiveness. J Strength Cond Res. 2008;22(4):1124-1129; doi: 10.1519/ JSC.0b013e31817394b9.

71. Macnaughton LS, Wardle S, Witard O, McGlory C, Hamilton DL, Jeromson S, et al. The response of muscle protein synthesis following whole-body resistance exercise is greater following $40 \mathrm{~g}$ than $20 \mathrm{~g}$ of ingested whey protein. Physiol Rep. 2016;4(15):e12893; doi: 10.14814/ phy2.12893.

72. Burke LM, Hawley JA, Wong SHS, Jeukendrup AE. Carbohydrates for training and competition. J Sports Sci. 2011;29(Suppl. 1):S17-S27; doi: 10.1080/02640414. 2011.585473.

73. Johnson EJ, Russell RM. Beta-carotene. In: Coates PM, Betz JM, Blackman MR, Cragg GM, Levine M, Moss J, et al. (eds.), Encyclopedia of dietary supplements, $2^{\text {nd }}$ ed. New York, London: Informa Healthcare; 2010; 115-120.

74. Solomons NW. Vitamin A. In: Bowman BA, Russell RM (eds.), Present knowledge in nutrition, $9^{\text {th }}$ ed. Washington, DC: International Life Sciences Institute; 2006; 157-183.

75. Institute of Medicine, Food and Nutrition Board. Dietary reference intakes for vitamin A, vitamin K, arsenic, boron, chromium, copper, iodine, iron, manganese, molybdenum, nickel, silicon, vanadium, and zinc. Washington, DC: National Academies Press; 2001.

76. Ross AC. Vitamin A. In: Coates PM, Betz JM, Blackman MR, Cragg GM, Levine M, Moss J, et al. (eds.), Encyclopedia of dietary supplements, $2^{\text {nd }}$ ed. New York, London: Informa Healthcare; 2010; 778-791.

77. Great Britain Department of Health. Nutrition and bone health with particular reference to calcium and vitamin D. Report of the Subgroup on Bone Health Working Group on the Nutritional Status of the Population of the Committee on Medical Aspects of Food and Nutrition Policy. Report on health and social subjects. London: The Stationery Office; 1998.

78. Szulc P, Arlot M, Chapuy MC, Duboeuf F, Meunier PJ, Delmas PD. Serum undercarboxylated osteocalcin correlates with hip bone mineral density in elderly women. J Bone Miner Res. 1994;9(10):1591-1595; doi: 10.1002/ jbmr.5650091012.

79. Shearer MJ. Role of vitamin K and Gla proteins in the pathophysiology of osteoporosis and vascular calcification. Curr Opin Clin Nutr Metab Care. 2000;3(6):433438; doi: 10.1097/00075197-200011000-00004.

80. New SA, Robins SP, Campbell MK, Martin JC, Garton MJ, Bolton-Smith C, et al. Dietary influences on bone mass and bone metabolism: further evidence of a positive link between fruit and vegetable consumption and bone health? Am J Clin Nutr. 2000;71(1):142-151; doi: 10.1093/ajen/71.1.142.

81. Favus MJ, American Society for Bone and Mineral Research. Primer of the metabolic bone diseases and disorders of mineral metabolism, $4^{\text {th }}$ ed. Philadelphia: Lippincott Williams \& Wilkins; 1999.

82. Strause L, Saltman P, Smith KT, Bracker M, Andon MB. Spinal bone loss in postmenopausal women supplemented with calcium and trace minerals. J Nutr. 1994; 124(7):1060-1064; doi: 10.1093/jn/124.7.1060.

83. Meacham SL, Taper LJ, Volpe SL. Effects of boron supplementation on bone mineral density and dietary, blood and urinary calcium, phosphorus, magnesium and boron in female athletes. Environ Health Perspect. 1994;102 (Suppl. 7):79-82; doi: 10.1289/ehp.94102s779.

84. Murray-Kolb LE, Beard J. Iron. In: Coates PM, Betz JM, Blackman MR, Cragg GM, Levine M, Moss J, et al. (eds.), Encyclopedia of dietary supplements, $2^{\text {nd }}$ ed. New York, London: Informa Healthcare; 2010; 432-438.

85. Cook JD, Reddy MB. Effect of ascorbic acid intake on nonheme-iron absorption from a complete diet. Am J Clin Nutr. 2001;73(1):93-98; doi: 10.1093/ajcn/73.1.93. 
A. Amato, S. Baldassano, C. Cortis, J. Cooper, P. Proia, Physical activity, nutrition, and bone health

86. Loucks AB, Kiens B, Wright HH. Energy availability in athletes. J Sports Sci. 2011;29(Suppl. 1):S7-S15; doi: 10.1080/02640414.2011.588958.

87. Melin A, Tornberg AB, Skouby S, Faber J, Ritz C, Sjö$\operatorname{din} \mathrm{A}$, et al. The LEAF questionnaire: a screening tool for the identification of female athletes at risk for the female athlete triad. Br J Sports Med. 2014;48(7):540545; doi: 10.1136/bjsports-2013-093240.

88. Fudge BW, Westerterp KR, Kiplamai FK, Onywera VO, Boit MK, Kayser B, et al. Evidence of negative energy balance using doubly labelled water in elite Kenyan endurance runners prior to competition. Br J Nutr. 2006;95(1):59-66; doi: 10.1079/BJN20051608.

89. Drenowatz C, Eisenmann JC, Carlson JJ, Pfeiffer KA, Pivarnik JM. Energy expenditure and dietary intake during high-volume and low-volume training periods among male endurance athletes. Appl Physiol Nutr Metab. 2012;37(2):199-205; doi: 10.1139/h11-155.

90. Henriksen DB, Alexandersen P, Bjarnason NH, Vilsbøll T, Hartmann B, Henriksen EE, et al. Role of gastrointestinal hormones in postprandial reduction of bone resorption. J Bone Miner Res. 2003;18(12):21802189; doi: 10.1359/jbmr.2003.18.12.2180.

91. Henriksen DB, Alexandersen P, Hartmann B, Adrian CL, Byrjalsen I, Bone HG, et al. Four-month treatment with GLP-2 significantly increases hip BMD: a randomized, placebo-controlled, dose-ranging study in postmenopausal women with low BMD. Bone. 2009;45(5):833842; doi: 10.1016/j.bone.2009.07.008.

92. De Sousa MV, Pereira RM, Fukui R, Caparbo VF, da Silva ME. Carbohydrate beverages attenuate bone resorption markers in elite runners. Metabolism. 2014;63(12): 1536-1541; doi: 10.1016/j.metabol.2014.08.011.

93. Sale C, Varley I, Jones TW, James RM, Tang JC, Fraser WD, et al. Effect of carbohydrate feeding on the bone metabolic response to running. J Appl Physiol. 2015; 119(7):824-830; doi: 10.1152/japplphysiol.00241.2015.

94. Haakonssen EC, Ross ML, Knight EJ, Cato LE, Nana A, Wluka AE, et al. The effects of a calcium-rich pre-exercise meal on biomarkers of calcium homeostasis in competitive female cyclists: a randomised crossover trial. PLoS One. 2014;10(5):e0123302; doi: 10.1371/ journal.pone.0123302.

95. Jenkins DJ, Jenkins AL, Wolever TM, Collier GR, Rao AV, Thompson LU. Starchy foods and fiber: reduced rate of digestion and improved carbohydrate metabolism. Scand J Gastroenterol. 1987;22(Suppl. 129): 132-141; doi: 10.3109/00365528709095867.

96. Townsend R, Elliott-Sale K, Currell K, Fraser W, Sale C. Ingestion of carbohydrate and protein immediately after an exhaustive run suppresses bone resorption and increases bone formation in trained male endurance runners. Bone Research Society Annual Meeting, Liverpool 2016.

97. Van Spil WE, Drossaers-Bakker KW, Lafeber FP. Associations of CTX-II with biochemical markers of bone turnover raise questions on its tissue origin: data from
CHECK, a cohort study of early osteoarthritis. Ann Rheum Dis. 2013;72(1):29-36; doi: 10.1136/annrheum dis-2011-201177.

98. Ross AC, Manson JE, Abrams SA, Aloia JF, Brannon PM, Clinton SK, et al. The 2011 report on dietary reference intakes for calcium and vitamin D from the Institute of Medicine: what clinicians need to know. J Clin Endocrinol Metab. 2011;96(1):5358; doi: 10.1210/jc.2010-2704.

99. Khaw KT, Sneyd MJ, Compston J. Bone density, parathyroid hormone and 25-hydroxyvitamin D concentrations in middle aged women. BMJ. 1992;305(6848): 273-277.

100. Ooms ME, Roos JC, Bezemer PD, Van Der Vijgch WJ, Bouter LM, Lips P. Prevention of bone loss by vitamin D supplementation in elderly women: a randomised double-blind trial. J Clin Endocrinol Metab. 1995; 80(4):1052-1058; doi: 10.1210/jcem.80.4.7714065.

101. Dawson-Hughes B, Dallal GE, Krall EA, Sadowski L, Sahyoun N, Tannenbaum S. A controlled trial of the effect of calcium supplementation on bone density in postmenopausal women. NEngl J Med. 1990;323(13): 878-883; doi: 10.1056/NEJM199009273231305.

102. Barry DW, Hansen KC, van Pelt RE, Witten M, Wolfe P, Kohrt WM. Acute calcium ingestion attenuates exercise-induced disruption of calcium homeostasis. Med Sci Sports Exerc. 2011;43(4):617-623; doi: 10.1249/MSS.0b013e3181f79fa8.

103. Baer DJ, Rumpler WV, Miles CW, Fahey GC Jr. Dietary fiber decreases the metabolizable energy content and nutrient digestibility of mixed diets fed to humans. J Nutr. 1997;127(4):579-586; doi: 10.1093/ jn/127.4.579.

104. Gaskins AJ, Mumford SL, Zhang C, WactawskiWende J, Hovey KM, Whitcomb BW, et al. Effect of daily fiber intake on reproductive function: the BioCycle study. Am J Clin Nutr. 2009;90(4):1061-1069; doi: 10.3945/ajcn.2009.27990.

105. Manolagas SC. From estrogen-centric to aging and oxidative stress: a revised perspective of the pathogenesis of osteoporosis. Endocr Rev. 2010;31(3):266300; doi: 10.1210/er.2009-0024.

106. Almeida M, Iyer S, Martin-Millan M, Bartell SM, Han L, Ambrogini E, et al. Estrogen receptor- $\alpha$ signaling in osteoblast progenitors stimulates cortical bone accrual. J Clin Invest. 2013;123(1):394-404; doi: 10.1172/JCI65910.

107. Domazetovic V, Marcucci G, Iantomasi T, Brandi ML, Vincenzini MT. Oxidative stress in bone remodeling: role of antioxidants. Clin Cases Miner Bone Metab. 2017;14(2):209-216; doi: 10.11138/ccmbm/2017.14. 1.209 . 